\title{
Anti-proliferative effects of tricyclodecan-9-yl-xanthogenate (D609) involve ceramide and cell cycle inhibition
}

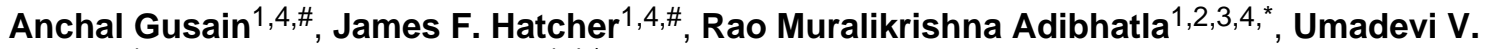 \\ Wesley ${ }^{1}$, and Robert J. Dempsey ${ }^{1,4,}{ }^{*}$ \\ ${ }^{1}$ Department of Neurological Surgery University of Wisconsin School of Medicine and Public \\ Health, Madison WI 53792 \\ ${ }^{2}$ Cardiovascular Research Center, University of Wisconsin School of Medicine and Public Health, \\ Madison, WI, USA \\ ${ }^{3}$ Neuroscience Training Program, University of Wisconsin School of Medicine and Public Health, \\ Madison, WI, USA \\ ${ }^{4}$ William S. Middleton Veterans Affairs Hospital, Madison, WI, USA
}

\begin{abstract}
Tricyclodecan-9-yl-xanthogenate (D609) inhibits phosphatidylcholine (PC)-phospholipase C (PLC) and/or sphingomyelin (SM) synthase (SMS). Inhibiting SMS can increase ceramide levels, which can inhibit cell proliferation. Here we examined how individual inflammatory and glia cell proliferation is altered by D609. Treatment with $100 \mu \mathrm{M}$ D609 significantly attenuated the proliferation of RAW 264.7 macrophages, $\mathrm{N} 9$ and BV-2 microglia, and $\mathrm{DITNC}_{1}$ astrocytes, without affecting cell viability. D609 significantly inhibited BrdU incorporation in BV-2 microglia and caused accumulation of cells in $G_{1}$ phase with decreased number of cells in the $S$ phase. D609 treatment for $2 \mathrm{~h}$ significantly increased ceramide levels in BV-2 microglia, which following a media change, returned to control levels $22 \mathrm{~h}$ later. This suggests that the effect of D609 may be mediated, at least in part, through ceramide increase via SMS inhibition. Western blots demonstrated that $2 \mathrm{~h}$ treatment of BV-2 microglia with D609 increased expression of the cyclin-dependent kinase (Cdk) inhibitor p21 and down-regulated phospho-retinoblastoma $(\mathrm{Rb})$, both of which returned to basal levels $22 \mathrm{~h}$ after removal of D609. Exogenous C8-ceramide also inhibited BV-2 microglia proliferation without loss of viability and decreased BrdU incorporation, supporting the involvement of ceramide in D609-mediated cell cycle arrest. Our current data suggest that D609 may offer benefit after stroke (Adibhatla and Hatcher 2010. Mol Neurobiol 41:206-217) through ceramide-mediated cell cycle arrest, thus restricting glial cell proliferation.
\end{abstract}

\section{Keywords}

astrocytes; BrdU; cell cycle; ceramide; flow cytometry; macrophages; microglia; p21; sphingomyelin synthase

\section{INTRODUCTION}

Xanthates including tricyclodecan-9-yl-xanthogenate (D609) were initially developed as broad spectrum anti-viral compounds (1, 2). D609 also has antioxidant properties (3, 4) due

\footnotetext{
*Correspondence to: Department of Neurological Surgery, University of Wisconsin, Box 8660 Clinical Science Center, 600 Highland Ave, Madison WI 53792. Phone: (608) 265-5967 adibhatl@neurosurg.wisc.edu; dempsey@ neurosurg.wisc.edu.

\# AG and JFH contributed equally to this manuscript.
} 
to the presence of the thiol function. D609 was shown to be a competitive inhibitor of bacterial phosphatidylcholine (PC)-specific phospholipase C (PC-PLC) and did not inhibit bacterial phosphatidylinositol-PLC, bovine pancreatic PLA 2 or phospholipase D from cabbage (5). Many of the actions of D609 have been attributed to PC-PLC inhibition, including suppressing expression of hypoxia-inducible factor la after stroke (6), reduced cytokine expression in lipopolysaccharide (LPS)-stimulated macrophages $(7,8)$, prevention of tumor necrosis factor-a or LPS-induced lethal shock in mice (9). A number of studies implicated PC-PLC in proliferation, differentiation, senescence and apoptosis in mammalian cells as well as a role in atherosclerosis (10) and indirectly in stroke models $(6,11,12)$. A review of the literature on D609 various mechanisms of action was recently published (1).

Cell proliferation and growth arrest are regulated by two lipid second messengers with opposing actions (13): ceramide and 1,2-diacylglycerol (DAG) that are connected through sphingomyelin (SM) synthase (SMS) pathway (14). SMS transfers the phosphocholine group from PC to ceramide to form SM and DAG. There are two forms of SMS: SMS1 is located in the Golgi apparatus and SMS2 in the plasma membrane (15). D609 inhibits both forms of SMS (16-18). Inhibition of SMS can result in increased ceramide levels by blocking its incorporation into SM. D609 inhibited bFGF-stimulated astrocyte proliferation, which was attributed to SMS inhibition (19).

After cerebral ischemia, proliferation of astrocytes and microglia contribute to glial scar formation and release of inflammatory factors (20). Cell proliferation is a precisely regulated process governed largely by cyclin-dependent kinases $(\mathrm{Cdks})$ and their respective cyclin binding proteins. In the $\mathrm{G}_{1}$ phase of the cell cycle, $\mathrm{Cdk} 4$ and $\mathrm{Cdk} 6$ bind to and are activated by D-type cyclins and initiate phosphorylation of retinoblastoma $(\mathrm{Rb})$ protein, releasing E2F transcription factors for transcription of genes required for cell cycle progression.

Subsequently, Cdk2 binds to and is activated by cyclin E, completing phosphorylation of $\mathrm{Rb}$, allowing further E2F transcription and progression into the S-phase of DNA replication (21). Activities of Cdk/cyclin complexes and cell cycle progression are regulated by two classes of Cdk inhibitors, the INK4 family and the Cip/Kip family p21 CIP1/WAF1, p27 Kip1 and $\mathrm{p} 57^{\mathrm{Kip} 2}$. Ceramide can inhibit proliferation by up-regulating the Cdk inhibitors p21 and p27 or de-phosphorylating $\mathrm{Rb}$ (22).

Our previous studies showed that D609 decreased infarct in an in vivo stroke model and upregulated p21 (23). In this study, we show that D609 inhibited proliferation of non-neuronal cell lines without inducing cell death. D609 treatment increased ceramide levels and upregulated p21 expression in BV-2 microglia. In addition, D609 hypo-phosphorylated Rb, resulting in inhibition of the cell cycle in the $\mathrm{G}_{0} / \mathrm{G}_{1}$ phase and a decrease in the proportion of cells in the S-phase. Exogenous C8-ceramide studies support the involvement of ceramide in D609-mediated cell cycle arrest.

\section{MATERIALS AND METHODS}

All chemicals and reagents unless stated otherwise were purchased from Sigma (St. Louis, MO). D609 was obtained from Kamiya Biomedical Company (Seattle, WA). The following antibodies were obtained from the indicated suppliers: p21 (BD Biosciences, San Diego, CA); phospho-Rb (Ser807/811) (Cell Signaling, Danvers, MA),horseradish peroxidase conjugated goat anti-rabbit and goat anti-mouse IgG (Bio-Rad, Hercules, CA). Western blot detection used SuperSignal West Pico chemiluminescent reagent (Pierce, Rockford, IL).

\section{CELL CULTURE}

The murine BV-2 microglia cell line developed by Dr V. Bocchini (24) was a generous gift from Dr Grace Y Sun (University of Missouri, Columbia, MO). Murine N9 microglial cells, 
originally developed by Prof. P. Ricciardi-Castagnoli (25) were kindly provided by Dr. Jyoti Watters (University of Wisconsin, Madison, WI). RAW 264.7 (26) and DITNC 1 (27) were procured from American Type Culture Collection (ATCC, Manassas, VA). All the cell lines were maintained in DMEM/high glucose containing $10 \%$ FBS with $100 \mathrm{U} / \mathrm{mL}$ penicillin and $100 \mu \mathrm{g} / \mathrm{mL}$ streptomycin. For all the experiments, cells were plated, allowed to attach overnight and specific treatments were given the next day. D609 was dissolved in sterile saline and added to cell cultures to give the desired concentration. D609 was stable in saline and cell culture media as measured by absorption maximum at $300 \mathrm{~nm} \mathrm{(28)}$ and $<10 \%$ decrease in absorption was observed after $24 \mathrm{hr}$ (personnel communication, H Kalluri) unlike the short half life previously reported (29). We also did not observe any absorption at $350 \mathrm{~nm}$ indicative of disulfide formation over $24 \mathrm{hrs}$ (28). C8-ceramide dissolved in 100\% $\mathrm{EtOH}$ was first dispersed in a small volume of media by gentle vortexing, then added to cultures of BV-2. There are two reasons to use C8-ceramide in our studies. 1) The structure of $\mathrm{C} 2$-ceramide is more like that of sphingosine than ceramides (30) and 2) C8-ceramide is also cell-permeable and its levels in treated cells and media could be analyzed using our existing GC method. Hexane used as solvent carrier for GC will mask the methyl esters derived from $\mathrm{C} 2$-or C6-ceramides.

\section{WESTERN BLOTTING}

Cells were lysed in protein extraction buffer consisting of $20 \mathrm{mM} \mathrm{Na}_{2} \mathrm{HPO}_{4}, 50 \mathrm{mM} \mathrm{NaF}$, $10 \mathrm{mM} \mathrm{Na}{ }_{4} \mathrm{P}_{2} \mathrm{O}_{7}, 150 \mathrm{mM} \mathrm{NaCl}, 5 \mathrm{mM}$ EGTA, $5 \mathrm{mM}$ EDTA, 2\% Triton X-100, and 0.5\% deoxycholate; $\mathrm{Na}_{3} \mathrm{VO}_{4}(1 \mathrm{mM})$ and Sigma protease inhibitor cocktail were added to the extraction buffer immediately prior to use. Cell lysates were briefly sonicated and centrifuged at $13,000 \mathrm{rpm}$ for $10 \mathrm{~min}$ at $4^{\circ} \mathrm{C}$. Supernatant was used for protein estimation by Lowry's method. Fifty $\mu \mathrm{g}$ of protein were loaded in each well of $10 \%$ or $12 \%$ polyacrylamide gels and subjected to SDS-PAGE at a constant voltage of $150 \mathrm{~V}$. Proteins were subsequently transferred to nitrocellulose at a constant voltage of $100 \mathrm{~V}$ for $1 \mathrm{~h}$. Nonspecific binding sites were blocked with $5 \%$ non-fat dry milk in 1x Tris buffered saline (TBS) with $0.05 \%$ Tween-20 (1x TBST) at room temperature for $1 \mathrm{~h}$. Blots were incubated with primary antibodies (diluted in either 5\% BSA or 5\% non-fat dry milk in 1x TBST) for overnight at $4^{\circ} \mathrm{C}$, washed with $1 \mathrm{x}$ TBST, then incubated with appropriate secondary antibodies for $1 \mathrm{~h}$ at room temperature. After washing, protein bands were visualized with SuperSignal West Pico. Blots were subsequently stripped and re-probed for $\beta$-actin as a loading control.

\section{BrdU LABELING}

BV-2 microglia were plated in 96 well plates at a density of $2 \times 10^{4}$ cells per well. Cells were treated with $100 \mu \mathrm{M}$ D609 for $2 \mathrm{~h}$ or $30 \mu \mathrm{M} \mathrm{C} 8$-ceramide for $2 \mathrm{~h}, 4 \mathrm{~h}$, and $6 \mathrm{~h}$. Chase was done with $5 \mu \mathrm{M}$ BrdU at $37 \mathrm{C}$ for $2 \mathrm{~h}$ followed by fixation in ice cold methanol for 10 min. DNA was denatured with $2 \mathrm{~N} \mathrm{HCl}$ for $30 \mathrm{~min}$. Cells ${ }^{\circ}$ were washed four times with $1 \mathrm{x}$ PBS after each step. Non specific sites were blocked with $10 \%$ normal donkey serum in $0.5 \%$ BSA and $0.4 \%$ Triton-X100 for 45 min at RT. Cells were incubated with anti-BrdU primary antibody (1:50, Invitrogen) overnight at $4{ }^{\circ} \mathrm{C}$. After four washings, cells were probed with Alexafluor-488 conjugated donkey anti mouse (1:500, Molecular Probes) for 1 h. Nuclei were counter-stained with DAPI $(10 \mu \mathrm{g} / \mathrm{ml})$. Images were acquired with a Nikon TE300 epifluorescence microscope, then analyzed using ImageJ (public domain software available at http://rsbweb.nih.gov/ij/); results were expressed as the percentage of BrdUpositive nuclei. 


\section{CELL CYCLE ANALYSIS}

Cell cycle analysis was carried out as described by Yang et al (31). BV-2 cells were plated and allowed to attach overnight. After D609 treatment, cells were washed with PBS and trypsinized. Cells were pelleted and adjusted to a concentration of $1-2 \times 10^{6}$ cells $/ \mathrm{ml}$. Cells were fixed by adding $3 \mathrm{ml}$ of $100 \%$ ethanol drop-wise into $1 \mathrm{ml}$ of cell suspension with continuous vortexing. After fixation overnight at $-20^{\circ} \mathrm{C}$, cells were pelleted and resuspended gently in PBS with $1 \%$ BSA. After 2 washes, cells were suspended in propidium iodide (PI) staining solution $(50 \mu \mathrm{g} / \mathrm{ml} \mathrm{PI,} 1 \mathrm{mg} / \mathrm{ml} \mathrm{RNase,} 0.5 \%$ triton-X) for 30 min at $37^{\circ} \mathrm{C}$ in the dark and the cell cycle was analyzed using a flow cytometer (BD Biosciences, FACSCalibur). Data were analyzed using MODFIT cell cycle analysis program.

\section{LIPID ANALYSIS}

Cell pellets were re-suspended in $0.5 \mathrm{~mL}$ saline and an aliquot was taken for protein measurement. The cell suspension was transferred into $3 \mathrm{~mL}$ of $\mathrm{CHCl}_{3}: \mathrm{MeOH}$ 1:2, followed by additional saline and $\mathrm{CHCl}_{3}(23)$. The $\mathrm{CHCl}_{3}$ layer containing the lipid extract was evaporated under a stream of nitrogen and re-dissolved in a small volume of $\mathrm{CHCl}_{3}: \mathrm{MeOH}$ 9:1. Ceramide was separated on silica gel $\mathrm{H}$ plates (Analtech) developed in $\mathrm{CHCl}_{3}: \mathrm{MeOH}: \mathrm{CH}_{3} \mathrm{COOH}$ (94:2:5). SM was separated on Whatman LK-5 silica gel plates using $\mathrm{CHCl}_{3}: \mathrm{EtOH}: \mathrm{Et}_{3} \mathrm{~N}: \mathrm{H}_{2} \mathrm{O}$ (30:35:35:7). Lipids were identified using authentic standards. DAG, ceramide and SM bands were then scraped into $1.5 \mathrm{~mL} \mathrm{MeOH}$ containing $30 \mu \mathrm{L}$ of $\mathrm{H}_{2} \mathrm{SO}_{4}$ and $10 \mathrm{nmol}$ of heptadecanoic acid (17:0) as an internal standard. SM and ceramide were methylated by heating at $100^{\circ} \mathrm{C}$ for $2 \mathrm{~h}$, DAG was methylated by heating at $70^{\circ} \mathrm{C}$ for $30 \mathrm{~min}(11,23)$. Fatty acid methyl esters were extracted into hexane and analyzed by gas chromatography. For analysis of C8-ceramide in media, $0.5 \mathrm{~mL}$ aliquots of media were extracted and $\mathrm{C} 8$-ceramide was separated on silica gel $\mathrm{H}$ plates and analyzed by gas chromatography as above.

\section{STATISTICAL ANALYSES}

Data were analyzed by ANOVA followed by Bonferroni post test for comparison of three or more groups or by non-paired $t$-test for comparison between two groups. A $p$ value of 0.05 or less was taken as significant.

\section{RESULTS}

\section{Lower doses and shorter durations of D609 treatment did not induce caspase-3 activation}

The goal of our experiments was to determine if D609 could inhibit cell proliferation without inducing apoptosis or cell death. D609 has been shown to induce apoptosis dependent on the dose and duration of exposure (32). BV-2 microglia treated with 50 or 100 $\mu \mathrm{M}$ D609 for $2 \mathrm{~h}$ followed by $22 \mathrm{~h}$ in media without D609 appeared morphologically normal and showed no significant trypan blue staining, whereas at $200 \mu \mathrm{M}$ many cells appeared shrunken and stained. Western blots were then conducted for pro-caspase- 3 cleavage as a marker for induction of the apoptotic pathway (33). Treatment of BV-2 with 50 or $100 \mu \mathrm{M}$ D609 caused no detectable cleavage of caspase-3, whereas $200 \mu \mathrm{M}$ D609 resulted in caspase-3 activation, indicating induction of apoptosis (Fig. 1A).

The time-course of D609 exposure on activation of caspase-3 was also investigated. BV-2 cells were treated with $100 \mu \mathrm{M}$ D609 since $200 \mu \mathrm{M}$ for $2 \mathrm{~h}$ induced apoptosis and preliminary findings indicated that $50 \mu \mathrm{M}$ had no effect on cell numbers compared with controls $22 \mathrm{~h}$ after treatment. Exposure of BV-2 to $100 \mu \mathrm{M}$ D609 for $2 \mathrm{~h}$ did not result in 
any detectable caspase-3 cleavage, whereas exposure for $8 \mathrm{~h}$ or longer induced caspase-3 activation (Fig. 1B). The results in Figs. 1A and 1B demonstrate that $100 \mu \mathrm{M}$ D609 for $2 \mathrm{~h}$ did not result in caspase- 3 activation immediately following the treatment and there was no delayed induction following $2 \mathrm{~h}$ treatment and $22 \mathrm{~h}$ in media without D609.

\section{D609 inhibited proliferation of various cell lines}

The effect of D609 on proliferation of RAW 264.7 macrophages, BV-2 and N9 microglia and DITNC 1 astrocytes was investigated. D609 significantly inhibited proliferation of all 4 cell lines (Fig. 2) without causing cell death, as viability remained $>90 \%$ by trypan blue exclusion in all cases. These data demonstrate that the inhibitory effect of D609 on cell proliferation is not unique to a particular cell line and also suggest that D609 may inhibit the cell cycle.

\section{D609 inhibited BrdU incorporation and caused cell cycle arrest in $G_{0} / G_{1}$ phase}

To assess the effect of D609 on the cell cycle, further studies were conducted using the BV-2 cell line. BV-2 were treated with $100 \mu \mathrm{M}$ D609 for $2 \mathrm{~h}$ followed by a $2 \mathrm{~h}$ incubation with BrdU without D609. Two sets of images were captured from 4 wells each from controls and D609 treated. Representative images are presented in Fig 3A and results are presented as the percentage of BrdU-positive cells (Fig. 3B). D609 treatment significantly decreased the percent of BrdU-positive cells, indicating fewer cells progressing into the Sphase of the cell cycle.

Based on the BrdU uptake studies, cell cycle analysis was done in BV-2 by flow cytometric analysis of PI staining. After $2 \mathrm{~h}$ D609 treatment followed by $2 \mathrm{~h}$ in media without D609, the percentage of the BV-2 cells in the $\mathrm{G}_{1}$ phase increased (54.3 $\pm 1.5 \%$ ) as compared with the control $(43.4 \pm 3.9 \%)$, whereas the percentage of cells in the $\mathrm{S}$ phase showed a significant dip $(39.9 \pm 3.3 \%)$ as compared with control $(48.8 \pm 2.4 \%)$ (Fig. 4). No significant change in the proportion of cells in each cell cycle phase was found following D609 exposure for $2 \mathrm{~h}$ alone (data not shown).

\section{D609 increased ceramide levels and altered expression of cell cycle proteins}

Since D609 inhibits SMS, which could cause cellular ceramide levels to increase and possibly to decrease DAG levels, ceramide levels were measured in BV-2 cells treated with $100 \mu \mathrm{M}$ D609 for $2 \mathrm{~h}$, and following a media change and further incubation without D609 for an additional $2 \mathrm{~h}$ and $22 \mathrm{~h}$. These conditions corresponded with treatment of BV-2 with D609 for cell proliferation by cell counts and BrdU incorporation. Ceramide levels were normalized to protein content and results are presented in Fig. 5A. Ceramides in BV-2 cells contained primarily the fatty acids palmitic (16:0), lignoceric (24:0) and nervonic (24:1); results are given for the sum of these three forms. D609 treatment for $2 \mathrm{~h}$ resulted in a significant increase in ceramide levels, which remained elevated for $2 \mathrm{~h}$ after removal of the agent. Following further incubation for $22 \mathrm{~h}$ without D609, ceramide levels returned to control levels. These results show that D609 treatment of BV-2 cells caused a transient, reversible increase in ceramide. Under these same treatment conditions, D609 did not cause DAG levels to decrease, but instead a significant increase was observed (Table 1).

The increase in ceramide by D609 prompted us to examine whether D609 could increase expression of the Cdk inhibitor p21 and down-regulate phosphorylation of $\mathrm{Rb}$ (phospho$\mathrm{Rb}$ ). BV-2 cells were treated as above with $100 \mu \mathrm{M}$ D609 and harvested after $2 \mathrm{~h}$ exposure and following $2 \mathrm{~h}$ and $22 \mathrm{~h}$ incubation without the agent and processed for Western blotting. In parallel with the increase in ceramide, D609 treatment for $2 \mathrm{~h}$ up-regulated p21 expression and caused a decrease in phospho-Rb (Fig. 5B), consistent with inhibition of the 
cell cycle. These alterations normalized to control levels $22 \mathrm{~h}$ after removal of the agent

(Fig. 5B), indicating that the cells have returned to a proliferative state.

\section{Exogenous C8-ceramide: effect on cell proliferation, viability and cellular uptake}

To determine the specific role of ceramide in D609-mediated inhibition of proliferation, BV-2 cells were treated with varying concentrations of cell-permeable C8-ceramide (34). Cell counts and viability were determined after $24 \mathrm{~h}$. Treatment of BV-2 cells with $30 \mu \mathrm{M}$ C8-ceramide for $24 \mathrm{~h}$ significantly inhibited proliferation (Fig. 6A) without inducing cell death (viability: controls $94 \pm 0.2 \%$ vs $\mathrm{C} 8$-ceramide $93 \pm 0.5 \%, \mathrm{n}=3$ each). Treatment with $20 \mu \mathrm{M}$ C8-ceramide had no significant effect on proliferation, whereas $40 \mu \mathrm{M}$ resulted in significant cell death (data not shown). Based on these results, $30 \mu \mathrm{M} \mathrm{C} 8$-ceramide was used for treatment of BV-2 cells in further studies.

Cellular ceramide levels were analyzed following $2 \mathrm{~h}$ and $24 \mathrm{~h}$ exposure to $30 \mu \mathrm{M} \mathrm{C} 8$ ceramide to determine uptake by BV-2 cells (Table 2). Following $2 \mathrm{~h}$ incubation, C8ceramide levels had reached $6529 \pm 245 \mathrm{pmol} / \mathrm{mg}$ protein, demonstrating substantial uptake (Fig. 6B). No C8-ceramide was detected in untreated cells. Interestingly, the endogenous forms of ceramide comprised of 16:0, 24:0 and 24:1 fatty acids also showed significant increases (Fig. 6B). Following $24 \mathrm{~h}$ exposure to $\mathrm{C} 8$-ceramide, cellular levels of C8-ceramide had declined to $<10 \%$ of the $2 \mathrm{~h}$ levels. The endogenous forms had also declined to less than half the $2 \mathrm{~h}$ levels and were not significantly elevated above controls (Fig. 6B).

Treatment of BV-2 with C8-ceramide resulted in a small but not significant increase in SM due to incorporation of C8-ceramide (controls $8.17 \pm 0.40$ vs $2 \mathrm{~h} \mathrm{C}$-ceramide $9.36 \pm 0.07$ $\mathrm{nmol} / \mathrm{mg}$ protein, $\mathrm{n}=3$ each). SM in normal BV-2 was composed of 16:0, 24:0 and 24:1 fatty acids. After $2 \mathrm{~h}$, incorporation of C8-ceramide into SM accounted for $16.4 \pm 0.2 \%$ of total fatty acids of SM. At $24 \mathrm{~h}$, SM levels were $8.94 \pm 0.58 \mathrm{nmol} / \mathrm{mg}$ protein in BV-2 treated with C8-ceramide and the C8 content of SM had declined to $10.5 \pm 2.8 \%$ (Table 3).

Towards gaining insight onto the decline in ceramide levels in BV-2 exposed to C8ceramide for $24 \mathrm{~h}, \mathrm{C} 8$-ceramide levels in media from treated BV-2 cells were analyzed and found to have declined to $<1 \mu \mathrm{M}$ by $24 \mathrm{~h}$ (Table 4 ). As a stability control, $30 \mu \mathrm{M} \mathrm{C} 8$ ceramide was added to control media and incubated at $37^{\circ} \mathrm{C}$ without cells. C8-ceramide levels remained constant for up to $24 \mathrm{~h}$ (Table 4), demonstrating that there was no decomposition.

\section{Exogenous C8-ceramide inhibited BrdU uptake}

To further assess the mechanism of exogenous $\mathrm{C} 8$-ceramide mediated inhibition of cell proliferation, BV-2 cells were treated with $30 \mu \mathrm{m} \mathrm{C} 8$-ceramide for $2 \mathrm{~h}, 4 \mathrm{~h}$ and $6 \mathrm{~h}$ followed by $2 \mathrm{~h}$ BrdU chase without C8-ceramide. Representative images are presented in Fig 7A and results are presented as the percentage of BrdU-positive cells (Fig.7B). C8-ceramide treatment for $2 \mathrm{~h}$ or $4 \mathrm{~h}$ did not significantly decrease the percent of BrdU positive cells compared to controls (data not shown), whereas BrdU incorporation was significantly inhibited by $6 \mathrm{~h}$ C8-ceramide treatment, indicating fewer cells entering the $\mathrm{S}$ phase.

\section{DISCUSSION}

Our previous findings in an in vivo stroke model showed that D609 treatment up-regulated the Cdk inhibitor p21 (23). Since ceramide can up-regulate p21 (22), we hypothesized that D609 increased p21 expression through inhibition of SMS and increased ceramide levels, and that this would result in cell cycle inhibition. We therefore examined the effect of D609 on proliferation of microglia, macrophage and astrocyte cell lines. Since ceramide also induces apoptosis $(35,36)$, we considered that over-induction of ceramide accumulation by 
D609 would result in cell death but that moderate increases may cause growth arrest without affecting cell viability.

Utilizing the BV-2 microglia cell line, our studies showed that D609 could cause caspase-3 cleavage, indicative of apoptosis, or inhibit cell proliferation without causing cell death, and that inhibition of the cell cycle $v s$ induction of apoptosis was dependent on the dose and duration of exposure. These data are consistent with previous reports demonstrating that D609 treatment of bFGF-stimulated neural stem cells for 1 to 3 days induced apoptosis (32). In other studies, a shorter $4 \mathrm{~h}$ exposure to D609 inhibited $\left[{ }^{3} \mathrm{H}\right]$-thymidine uptake in bFGFstimulated astrocytes (19). Our results showed that D609 could inhibit proliferation of microglia, macrophage and astrocyte cell lines, indicating that this effect is not unique to a specific cell line. However, previous studies have not examined the effect of D609 on expression of cell cycle regulating proteins. Utilizing the BV-2 microglia cell line, our studies demonstrated that D609 increased ceramide levels and induced expression of cyclin/ Cdk inhibitory protein $\mathrm{p} 21$, resulting in a decrease in cells in the $\mathrm{S}-$ and $\mathrm{G}_{2} / \mathrm{M}$ phases due to a block in the cell cycle in $\mathrm{G}_{0} / \mathrm{G}_{1}$. Interestingly D609 treatment did not cause a decrease in levels of DAG that is classically associated with cell proliferation (13), but rather a significant increase was observed (Table 1), supporting the role of ceramide in antiproliferative effects. The increase in DAG might represent a cellular response to maintain homeostasis (14). On an average the lipid levels (nmol/mg protein) in BV-2 microglia cells are: PC 35-45; SM 7.5-9; DAG 2-2.5; while ceramide levels are <0.5. Since the levels of ceramide are a small fraction of PC, SM and DAG, observing changes in these lipid pools due to SMS inhibition might be masked. Treatment of BV-2 cells with exogenous C8ceramide also inhibited cell proliferation and BrdU incorporation, supporting the role of ceramide in D609-mediated inhibition of cell proliferation. The effect of D609 on proliferation of BV-2 microglia appeared to be more robust than treatment with exogenous C8-ceramide. Since ceramide is highly hydrophobic, it generally resides in cellular membranes and its effects are strongly influenced by cellular compartmentalization (37). Exogenous short-chain ceramides are transported to the Golgi apparatus following cellular uptake $(38,39)$. D609 inhibition of both forms of SMS (16-18) could result in ceramide increases in both Golgi apparatus and plasma membrane due to the sub-cellular localizations of SMS1 (Golgi apparatus) and SMS2 (plasma membrane) (15). C8-ceramide was incorporated into sphingomyelin demonstrated by formation of C8-SM (Table 3), evidence that some of C8-ceramide reached the pool used by SMS. The effects of ceramide subcellular distribution in its signaling remain an important topic for future exploration.

Incubation of BV-2 with C8-ceramide resulted in a nearly 4-fold increase in endogenous forms of ceramide after $2 \mathrm{~h}$. Other studies have demonstrated large increases in endogenous ceramides in Madin-Darby canine kidney cells treated with C8-ceramide (40) and in A549 human lung adenocarcinoma cells treated with C6-ceramide $(41,42)$. There is substantial evidence that this increase in endogenous ceramides is due to remodeling of short chain ceramides through de-acylation to sphingosine by ceramidases, followed by re-acylation with longer-chain fatty acids via the ceramide re-cycling pathway $(35,41-43)$. There is evidence that growth inhibition and cell cycle arrest induced by exogenous C6-ceramide may be mediated by the increases in endogenous long-chain ceramides (42). Ceramide functions are chain length dependent (eg. C16:0; C24:0' C24:1) that may ultimately decide the fate of cellular events such as apoptosis, proliferation or cell cycle arrest (41).

One unexpected finding in BV-2 cells treated with C8-ceramide was the normalization of ceramide to near control levels by $24 \mathrm{~h}$ since the cultures did not undergo a media change. This prompted us to establish the stability of $\mathrm{C} 8$-ceramide in the culture media and also measure levels in the media from BV-2 cells after treatment with C8-ceramide (Table 4). Our data showed no decrease in C8-ceramide concentration over $24 \mathrm{~h}$ in culture media 
incubated at $37^{\circ} \mathrm{C}$ in the absence of cells, demonstrating stability of the analog. However, C8-ceramide levels in media from BV-2 cells declined rapidly and decreased to $<1 \mu \mathrm{M}$ by $24 \mathrm{~h}$. The decrease in both culture media and cellular levels indicates near complete metabolism of the analog by the BV-2 cells by $24 \mathrm{~h}$, without incorporation into SM. While we did not examine the metabolism of exogenous C8-ceramide in BV-2 cells since the focus of these studies was the role of D609 in cell proliferation, our data indicate an additional factor to be considered in interpreting results from exogenous ceramide treatments. It has been noted that, since ceramides partition in membranes, the concentration of ceramide in relation to the number of cells is a significant factor influencing the outcome due to surface concentration effects, i.e., fewer cells treated with the same concentration of ceramide may respond differently than if the cell density is higher (36). Our data indicate that in addition to surface concentration effects, metabolism of ceramide by the cells may be another factor since higher density cultures will metabolize a given amount of ceramide faster than low density cultures, altering the overall response.

Recent studies showed that 2-hydroxyoleic acid (2OHOA) stimulates SMS and cause cell cycle arrest, cell differentiation, and autophagy or apoptosis in cancer cells (44). Normal (non-tumor MRC-5) cells were unaffected by 2OHOA. Status of ceramide levels as well as effect of D609 alone on these cell lines were not presented. These effects may be specific to cell type and experimental conditions. Barcelo-Coblijn et al 2011 also have observed antiproliferative effects for D609 (personnel communication, Drs Halver and Escriba PNAS 2011 paper corresponding authors of (44)). In these studies 2OHOA increased SM levels > 2.5 times in A549 and 5 times in U118 cells compared to controls, which may drastically affect the plasma membrane phospholipid composition/distribution. It was also unclear the source of ceramide needed for this large increase in SM synthesis.

Our studies demonstrated reduction of cerebral infarct by D609 treatment in a rat stroke model and attributed the protection by D609 to cell cycle regulation (23). After stroke, expression of cell cycle-related proteins is up-regulated. There is a dual effect to induction of the cell cycle. Proliferation of astrocytes and microglia contributes to glial scar formation and release of inflammatory factors (20). Mature neurons are post-mitotic, yet apparently must continuously hold the cell cycle in check (45). Failure of this cell cycle control in mature neurons results not in proliferation but cell death. Thus inhibition of the cell cycle after stroke would attenuate astrocyte and microglia proliferation and also rescue neurons from cell death due to aberrant cell cycle induction. This is supported by studies demonstrating that administration of cell cycle inhibitors after ischemia dramatically reduced neuronal death (46).

Whether inflammatory responses after injury are harmful or helpful to recovery is a complex issue $(47,48)$. TNF produced by microglia offered protection to neurons after ischemia (49). Ablation of proliferating microglia resulted in an increase in the number of cells (unknown identity) expressing pro-inflammatory cytokines (50). In the absence of activated microglia/ macrophages which cells are the source of pro-inflammatory cytokines is unclear? Defining the role of microglia/macrophages in CNS pathologies is a challenge since they are the source for both pro-inflammatory cytokines as well as neurotrophic factors (51). Our current studies show that D609 inhibited proliferation of RAW 264.7 macrophages and three glia cells lines (BV-2 and $\mathrm{N} 9$ microglia and DITNC 1 astrocytes) and thus may provide benefit after stroke by inhibiting proliferation of astrocytes and microglia. Another possibility is that D609 may prevent neuronal death by blocking aberrant induction of the cell cycle at the early reperfusion in mature neurons ( $24 \mathrm{hr}$ reperfusion), however may not interfere with proliferation of microglia/macrophages ( $72 \mathrm{hr}$ reperfusion) that are the source of trophic factors (52) during repair phase of stroke (23). 


\section{Acknowledgments}

Supported by NIH R01 NS063959 and AHA 11GRNT7360066 and resources provided byVeterans Affairs

Hospital, Madison, WI. The authors have no conflict of interest to declare.

\section{References}

1. Adibhatla RM, Hatcher JF, Gusain A. Tricyclodecan-9-yl-xanthogenate (D609) mechanism of actions: A Mini-review of literature. Neurochem Res. 2012; 37:671-679. [PubMed: 22101393]

2. Sauer G, Amtmann E, Melber K, et al. DNA and RNA virus species are inhibited by xanthates, a class of antiviral compounds with unique properties. Proc Natl Acad Sci. 1984; 81:3263-3267. [PubMed: 6328507]

3. Sultana R, Newman SF, Abdul HM, et al. Protective effect of D609 against amyloid- $\beta$ 1-42 induced oxidative modification of neuronal proteins: Redox proteomics study. J Neurosci Res. 2006; 84:409-417. [PubMed: 16634065]

4. Zhou DH, Lauderback CM, Yu T, et al. D609 inhibits ionizing radiation-induced oxidative damage by acting as a potent antioxidant. J Pharmacol Exp Ther. 2001; 298:103-109. [PubMed: 11408530]

5. Amtmann E. The antiviral, antitumoural xanthate D609 is a competitive inhibitor of phosphatidylcholine-specific phospholipase C. Drugs Exp Clin Res. 1996; 22:287-294. [PubMed: 9034754]

6. Chen C, Hu Q, Yan J, et al. Multiple effects of 2ME2 and D609 on the cortical expression of HIF-1a and apoptotic genes in a middle cerebral artery occlusion induced focal ischemia rat model. J Neurochem. 2007; 102:1831-1841. [PubMed: 17532791]

7. Monick MM, Carter AB, Gudmundsson G, et al. A phosphatidylcholine-specific phospholipase C regulates activation of p42/44 mitogen-activated protein kinases in lipopolysaccharide-stimulated human alveolar macrophages. J Immunol. 1999; 162:3005-3012. [PubMed: 10072552]

8. Zhang F, Zhao G, Dong Z. Phosphatidylcholine-specific phospholipase C and D in stimulation of RAW264.7 mouse macrophage-like cells by lipopolysaccharide. Intl Immunopharmacol. 2001; 1:1375-1384.

9. Machleidt T, Kramer B, Adam D, et al. Function of the p55 TNF receptor "death domain" mediated by phosphatidylcholine-specific PLC. J Exp Med. 1996; 184:725-733. [PubMed: 8760826]

10. Zhang L, Zhao J, Su L, et al. D609 inhibits progression of preexisting atheroma and promotes lesion stability in apolipoprotein E-/- mice. A role of phosphatidylcholine-specific phospholipase in atherosclerosis. Arterioscler Thromb Vasc Biol. 2010; 30:411-418. [PubMed: 20139365]

11. Larsen EC, Hatcher JF, Adibhatla RM. Effect of tricyclodecan-9-yl potassium xanthate (D609) on phospholipid metabolism and cell death during oxygen-glucose deprivation in PC12 cells. Neuroscience. 2007; 146:946-961. [PubMed: 17434680]

12. Yu ZF, Nikolova-Karakashian M, Zhou DH, et al. Pivotal role for acidic sphingomyelinase in cerebral ischemia-induced ceramide and cytokine production, and neuronal apoptosis. J Mol Neurosci. 2000; 15:85-97. [PubMed: 11220788]

13. Ruvolo PP. Ceramide regulates cellular homeostasis via diverse stress signaling pathways. Leukemia. 2001; 15:1153-1160. [PubMed: 11480555]

14. Carrasco S, Merida I. Diacylglycerol, when simplicity becomes complex. Trends Biochem Sci. 2007; 32:27-36. [PubMed: 17157506]

15. Tafesse FG, Ternes P, Holthuis JCM. The multigenic sphingomyelin synthase family. J Biol Chem. 2006; 281:29421-29425. [PubMed: 16905542]

16. Huitema K, van den Dikkenberg J, Brouwers JFHM, et al. Identification of a family of animal sphingomyelin synthases. EMBO J. 2004; 23:33-44. [PubMed: 14685263]

17. Luberto C, Hannun YA. SM synthase, a potential regulator of intracellular levels of ceramide and diacylglycerol during SV40 transformation. Does SM synthase account for the putative PCspecific PLC? J Biol Chem. 1998; 273:14550-14559. [PubMed: 9603970]

18. Luberto C, Yoo DS, Suidan HS, et al. Differential effects of sphingomyelin hydrolysis and resynthesis on the activation of NF-kappa B in normal and SV40-transformed human fibroblasts. J Biol Chem. 2000; 275:14760-14766. [PubMed: 10799564] 
19. Riboni L, Viani P, Bassi R, et al. Basic fibroblast growth factor-induced proliferation of primary astrocytes. Evidence for the involvement of sphingomyelin biosynthesis. J Biol Chem. 2001; 276:12797-12804. [PubMed: 11278937]

20. Byrnes KR, Faden AI. Role of cell cycle proteins in CNS injury. Neurochem Res. 2007; 32:1799_ 1807. [PubMed: 17404835]

21. Wang W, Bu B, Xie M, et al. Neural cell cycle dysregulation and central nervous system diseases. Prog Neurobiol. 2009; 89:1-17. [PubMed: 19619927]

22. Ogretmen B, Hannun YA. Biologically active sphingolipids in cancer pathogenesis and treatment. Nat Rev Cancer. 2004; 4:604-616. [PubMed: 15286740]

23. Adibhatla RM, Hatcher JF. Protection by D609 through cell-cycle regulation after stroke. Mol Neurobiol. 2010; 41:206-217. [PubMed: 20148315]

24. Blasi E, Barluzzi R, Bocchini V, et al. Immortalization of murine microglial cells by a v-raf/v-myc carrying retrovirus. J Neuroimmunol. 1990; 27:229-237. [PubMed: 2110186]

25. Righi M, Mori L, De Libero G, et al. Monokine production by microglial cell clones. Eur J Immunol. 1989; 19:1443-1448. [PubMed: 2789141]

26. Raschke WC, Baird S, Ralph P, et al. Functional macrophage cell lines transformed by Abelson leukemia virus. Cell. 1978; 15:261-267. [PubMed: 212198]

27. Radany EH, Brenner M, Besnard F, et al. Directed establishment of rat brain cell lines with the phenotypic characteristics of type 1 astrocytes. Proc Natl Acad Sci. 1992; 89:6467-6471. [PubMed: 1378628]

28. Lauderback CM, Drake J, Zhou D, et al. Derivatives of xanthic acid are novel antioxidants: application to synaptosomes. Free Radic Res. 2003; 37:355-365. [PubMed: 12747729]

29. Bai A, Meier GP, Wang Y, et al. Prodrug modification increases potassium tricyclo[5.2.1.0 2,6]decan-8-yl dithiocarbonate (D609) chemical stability and cytotoxicity against U937 leukemia cells. J Pharmacol Exp Ther. 2004; 309:1051-1059. [PubMed: 14960662]

30. Furuya K, Ginis I, Takeda H, et al. Cell permeable exogenous ceramide reduces infarct size in spontaneously hypertensive rats supporting in vitro studies that have implicated ceramide in induction of tolerance to ischemia. J Cereb Blood Flow Metab. 2001; 21:226-232. [PubMed: 11295877]

31. Yang NC, Jeng KC, Ho WM, et al. DHEA inhibits cell growth and induces apoptosis in BV-2 cells and the effects are inversely associated with glucose concentration in the medium. J Steroid Biochem Mol Biol. 2000; 75:159-166. [PubMed: 11226832]

32. Wang N, Lv X, Su L, et al. D609 blocks cell survival and induces apoptosis in neural stem cells. Bioorg Med Chem Lett. 2006; 16:4780-4783. [PubMed: 16872828]

33. Yakovlev AG, Faden AI. Caspase-dependent apoptotic pathways in CNS injury. Mol Neurobiol. 2001; 24:131-144. [PubMed: 11831549]

34. Chiba N, Masuda A, Yoshikai Y, et al. Ceramide inhibits LPS-induced production of IL-5, IL-10, and IL-13 from mast cells. J Cell Physiol. 2007; 213:126-136. [PubMed: 17458900]

35. Bartke N, Hannun YA. Bioactive sphingolipids: metabolism and function. J Lipid Res. 2009; 50:S91-96. [PubMed: 19017611]

36. Luberto C, Kraveka JM, Hannun YA. Ceramide regulation of apoptosis versus differentiation: A walk on a fine line. Lessons from neurobiology. Neurochem Res. 2002; 27:609-617.

37. Hannun YA, Obeid LM. Many ceramides. J Biol Chem. 2011; 286:27855-27862. [PubMed: 21693702]

38. Fukunaga T, Nagahama M, Hatsuzawa K, et al. Implication of sphingolipid metabolism in the stability of the Golgi apparatus. J Cell Sci. 2000; 113(Pt 18):3299-3307. [PubMed: 10954427]

39. Lipsky NG, Pagano RE. A vital stain for the Golgi apparatus. Science. 1985; 228:745-747. [PubMed: 2581316]

40. Abe A, Wu D, Shayman JA, et al. Metabolic effects of short-chain ceramide and glucosylceramide on sphingolipids and protein kinase C. Eur J Biochem. 1992; 210:765-773. [PubMed: 1483461]

41. Grosch S, Schiffmann S, Geisslinger G. Chain length-specific properties of ceramides. Prog Lipid Res. 2012; 51:50-62. [PubMed: 22133871] 
42. Ogretmen B, Pettus BJ, Rossi MJ, et al. Biochemical mechanisms of the generation of endogenous long chain ceramide in response to exogenous short chain ceramide in the A549 human lung adenocarcinoma cell line. Role for endogenous ceramide in mediating the action of exogenous ceramide. J Biol Chem. 2002; 277:12960-12969. [PubMed: 11815611]

43. Takeda S, Mitsutake S, Tsuji K, et al. Apoptosis occurs via the ceramide recycling pathway in human HaCaT keratinocytes. J Biochem. 2006; 139:255-262. [PubMed: 16452313]

44. Barcelo-Coblijn G, Martin ML, de Almeida RF, et al. Sphingomyelin and sphingomyelin synthase (SMS) in the malignant transformation of glioma cells and in 2-hydroxyoleic acid therapy. Proc Natl Acad Sci. 2011; 108:19569-19574. [PubMed: 22106271]

45. Herrup K, Yang Y. Cell cycle regulation in the postmitotic neuron: oxymoron or new biology? Nat Rev Neurosci. 2007; 8:368-378. [PubMed: 17453017]

46. Osuga H, Osuga S, Wang F, et al. Cyclin-dependent kinases as a therapeutic target for stroke. Proc Natl Acad Sci. 2000; 97:10254-10259. [PubMed: 10944192]

47. Kriz J. Inflammation in ischemic brain injury: timing is important. Crit Rev Neurobiol. 2006; 18:145-157. [PubMed: 17725517]

48. Venero JL, Burguillos MA, Brundin P, et al. The executioners sing a new song: killer caspases activate microglia. Cell Death Differ. 2011; 18:1679-1691. [PubMed: 21836616]

49. Lambertsen KL, Clausen BH, Babcock AA, et al. Microglia protect neurons against ischemia by synthesis of tumor necrosis factor. J Neurosci. 2009; 29:1319-1330. [PubMed: 19193879]

50. Lalancette-Hebert M, Gowing G, Simard A, et al. Selective ablation of proliferating microglial cells exacerbates ischemic injury in the brain. J Neurosci. 2007; 27:2596-2605. [PubMed: 17344397]

51. Ekdahl CT, Kokaia Z, Lindvall O. Brain inflammation and adult neurogenesis: The dual role of microglia. Neuroscience. 2009; 158:1021-1029. [PubMed: 18662748]

52. Madinier A, Bertrand N, Mossiat C, et al. Microglial involvement in neuroplastic changes following focal brain ischemia in rats. PLoS ONE. 2009; 4:e8101. [PubMed: 19956568]

53. Day TW, Wu CH, Safa AR. Etoposide induces protein kinase Cdelta- and caspase-3-dependent apoptosis in neuroblastoma cancer cells. Mol Pharmacol. 2009; 76:632-640. [PubMed: 19549763]

54. Lee S, Suk K. Heme oxygenase-1 mediates cytoprotective effects of immunostimulation in microglia. Biochem Pharmacol. 2007; 74:723-729. [PubMed: 17632083] 

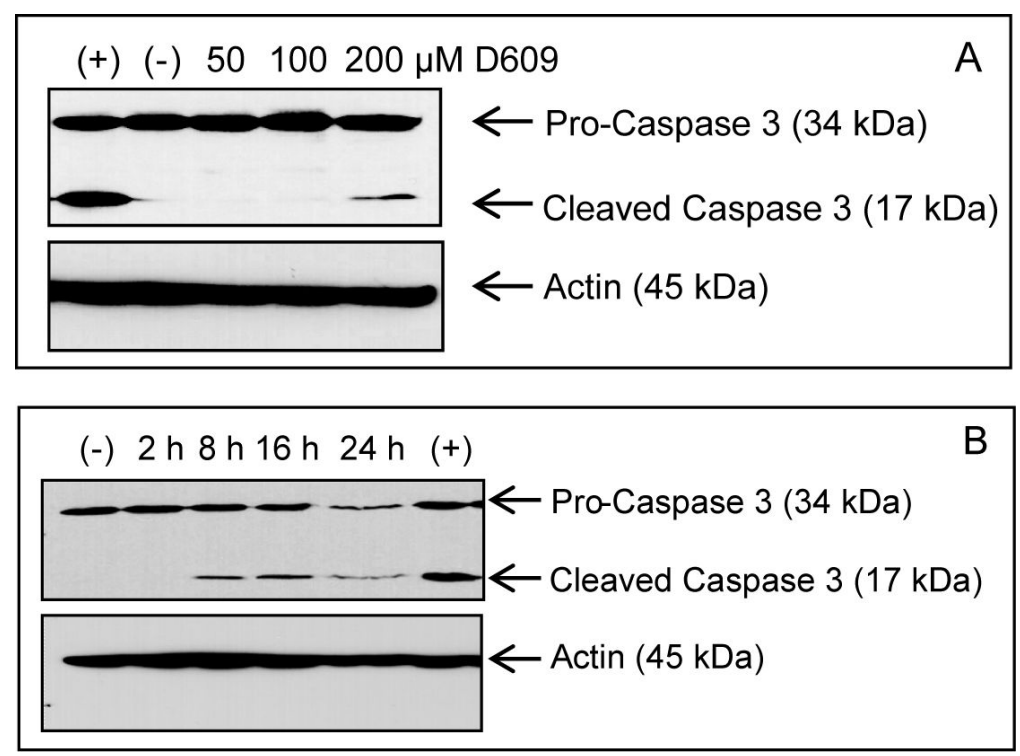

Fig. 1.

D609 activates caspase- 3 in a dose- and time-dependent manner. BV-2 cells treated with 20 $\mu \mathrm{M}$ etoposide for $24 \mathrm{~h}$ were used as a positive control for caspase- 3 activation $(53,54)$. (A): Western blot showing dose-response for D609 treatment of BV-2 cells for induction of cleaved caspase-3. Cells were incubated with 50, 100 and $200 \mu \mathrm{M}$ D609 for $2 \mathrm{~h}$, media was changed to remove D609 and cells were harvested after incubation for additional $22 \mathrm{~h}$.

Controls were incubated without D609. Lanes: 1) positive control (+), 2) untreated control (-), 3) $50 \mu \mathrm{M}$ D609, 4) $100 \mu \mathrm{M}$ D609, 5) $200 \mu \mathrm{M}$ D609. (B): Western blot showing effect of different treatment durations of BV-2 with $100 \mu \mathrm{M}$ D609 on caspase-3 cleavage. BV-2 cells were treated with $100 \mu \mathrm{M}$ D609 for $2 \mathrm{~h}, 8 \mathrm{~h}, 16 \mathrm{~h}$ and $24 \mathrm{~h}$ and harvested at the end of each respective treatment time. Lanes: 1) untreated control (-), 2) 2 h D609, 3$) 8$ h D609, 4) 16 h D609, 5) 24 h D609, 6) positive control (+). 

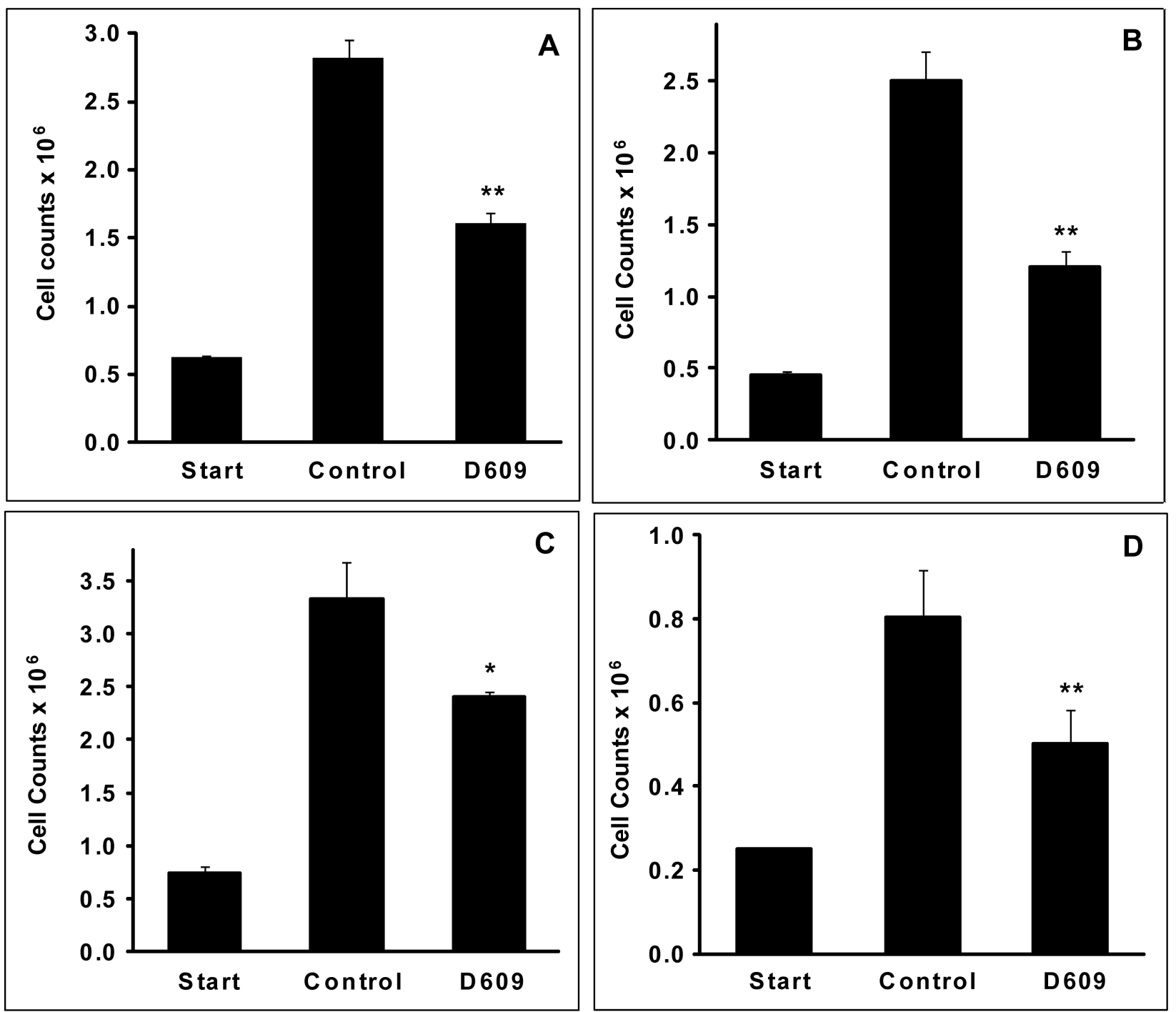

Fig. 2.

D609 inhibited proliferation of (A) BV-2 microglia, (B) N9 microglia, (C) RAW 264.7 macrophages and (D) DITNC ${ }_{1}$ astrocytes. Cell lines were first plated and allowed to adhere overnight. At the start of treatment, parallel dishes of cells were harvested and counted to determine the initial cell number. Cells were treated with $100 \mu \mathrm{M}$ D609 for $2 \mathrm{~h}$, followed by a media change. The media was centrifuged to recover any non-adherent cells, which were returned to the respective dishes. Cells were counted using a hemocytometer and viability was determined by trypan blue exclusion following $22 \mathrm{~h}$ incubation without D609. Viability was greater than $90 \%$ in all cells. $* \mathrm{p}<0.05$ and $* * \mathrm{p}<0.01$ compared with controls by unpaired $t$-test ( $\mathrm{n}=3$ /group). 
A

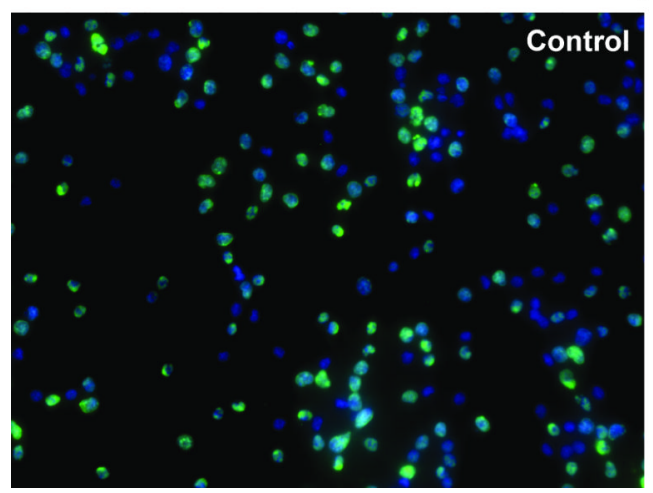

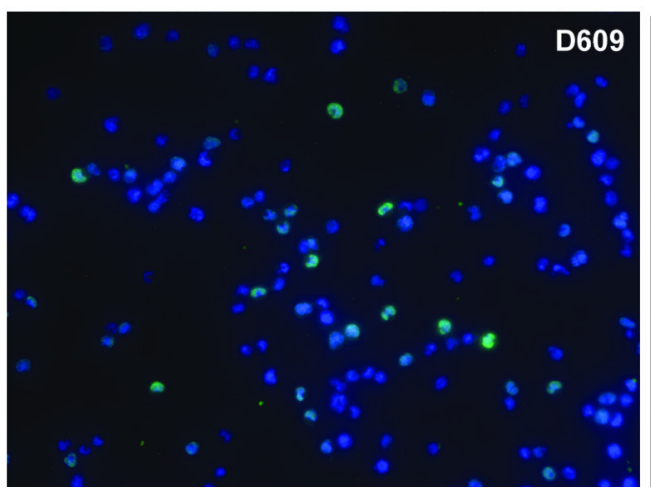

B

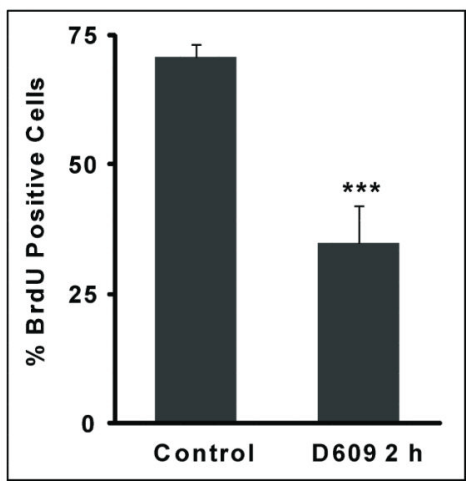

Fig. 3.

D609 inhibited BrdU incorporation in BV-2 cells. (A): BrdU uptake in BV-2 controls and cells treated with D609. Cells were plated in 96-well plates and allowed to attach overnight, then treated with $100 \mu \mathrm{M}$ D609 for $2 \mathrm{~h}$. The media was then replaced with fresh media containing BrdU and cells were incubated for $2 \mathrm{~h}$. Cells were labeled with anti-BrdU antibody followed by DAPI counterstaining, and imaged. Blue: DAPI, green: BrdU. Original magnification 200x. (B): Quantification of BrdU-positive cells as a percentage of total cells. $* * * \mathrm{p}<0.001$ compared with controls by unpaired $t$-test. 

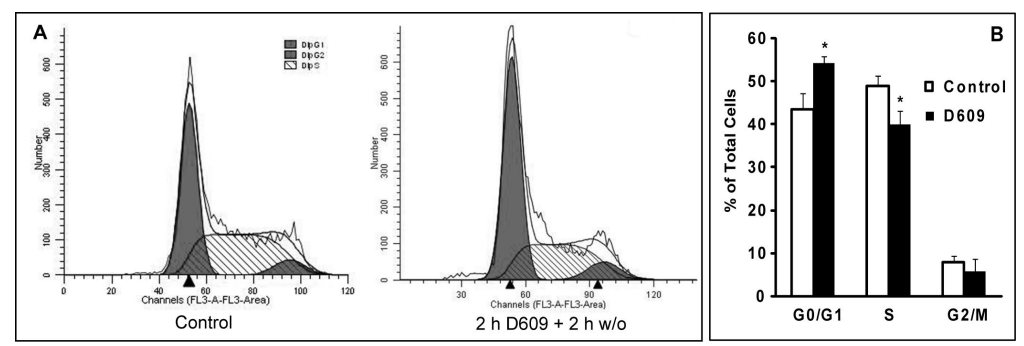

Fig. 4.

Effect of D609 treatment on cell cycle progression in BV-2 cells. (A): Representative DNA histogram from control and D609 treatment groups. BV-2 cells were treated with $100 \mu \mathrm{M}$ D609 for $2 \mathrm{~h}$ followed by $2 \mathrm{~h}$ in media without D609, then stained with propidium iodide. DNA content of the samples were analyzed by flow cytometry. (B): Quantification of the percentage of cells in each phase of cell cycle. $2 \mathrm{~h}$ D609 followed by $2 \mathrm{~h}$ in the media without D609 has arrested the cells in the $\mathrm{G}_{1}$ phase with a smaller percentage of cells entering into the $S$ phase. $* \mathrm{p}<0.05$ compared with controls by unpaired $t$-test; from 3 independent experiments. 

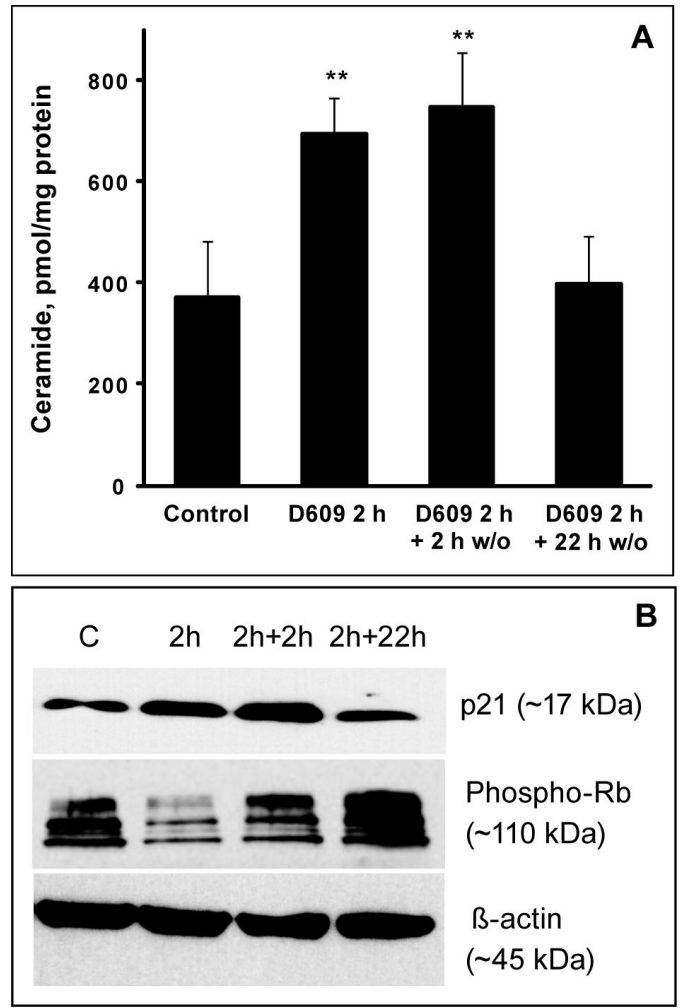

Fig. 5.

D609 increased ceramide levels and induced p21 expression in BV-2 cells. BV-2 cells were treated with $100 \mu \mathrm{M}$ D609 for $2 \mathrm{~h}$, then media was changed and cultures were incubated for an additional $2 \mathrm{~h}$ or $22 \mathrm{~h}$ without D609. (A): D609 increased ceramide levels in BV-2, which remained elevated for $2 \mathrm{~h}$ after removal of the agent and normalized to control levels after 22 h. ** p $<0.01$ compared with controls or D609 $2 \mathrm{~h}+22 \mathrm{~h}$ w/o by ANOVA with Bonferroni's post-test; $n=4$ per group from 2 independent experiments. Ceramide forms consisted mainly of palmitic (C16-ceramide), lignoceric (C24-ceramide) and nervonic (C24:1-ceramide). (B): Western blots demonstrating induction of p21 and down-regulation of pRb following D609 treatment. Lanes: 1) untreated control, 2) $100 \mu \mathrm{M}$ D609 2 hr, 3) 100 $\mu \mathrm{M}$ D609 $2 \mathrm{hr}+2 \mathrm{hr}$ w/o, 4) $100 \mu \mathrm{M}$ D609 $2 \mathrm{hr}+22 \mathrm{hr}$ w/o. 

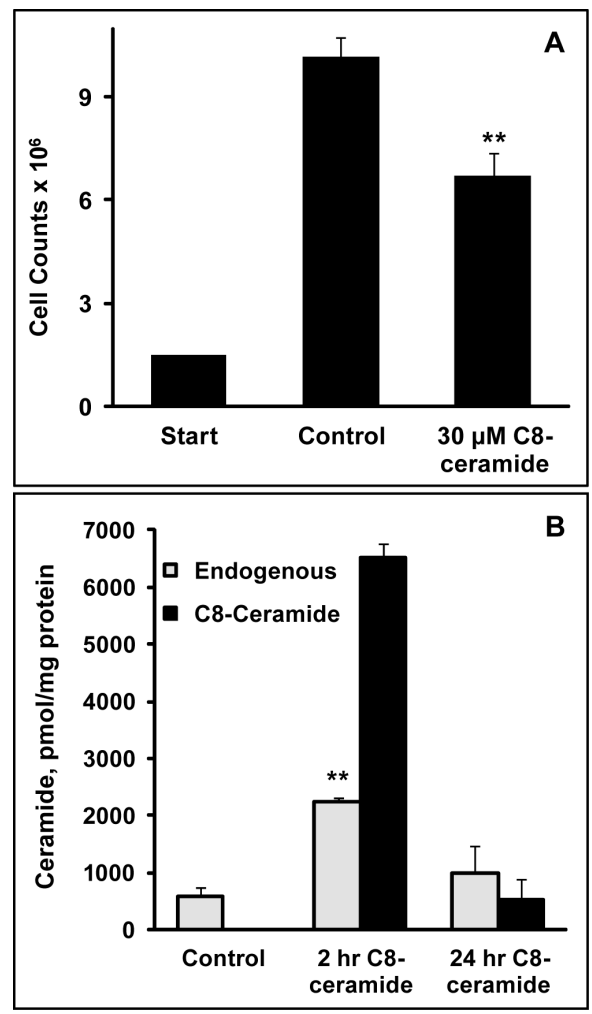

Fig. 6.

Exogenous C8-ceramide decreased cell proliferation in BV-2 cells. (A) $30 \mu \mathrm{M}$ C8-ceramide was added to BV-2 cultures and cell counts and viability were determined after $24 \mathrm{~h}$. ** $\mathrm{p}<$ 0.01 compared with controls by unpaired $t$-test. (B) Uptake of C8-ceramide and endogenous ceramide levels in BV-2 after $2 \mathrm{~h}$ and $24 \mathrm{~h}$ treatment with $30 \mu \mathrm{M} \mathrm{C} 8$-ceramide. $* * \mathrm{p}<0.01$ compared with controls by ANOVA with Bonferroni's post-test. 
A

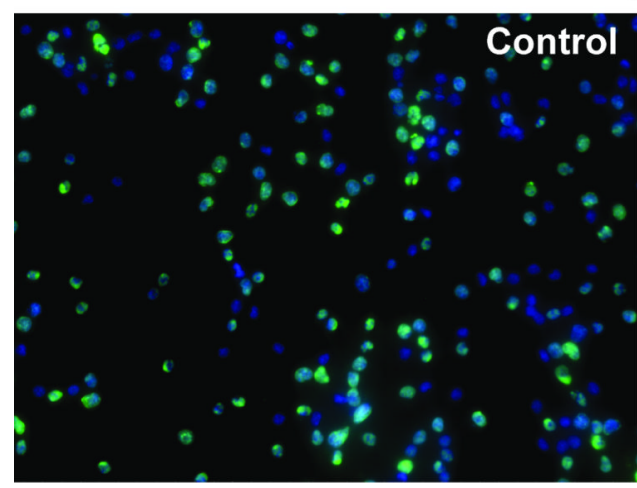

A

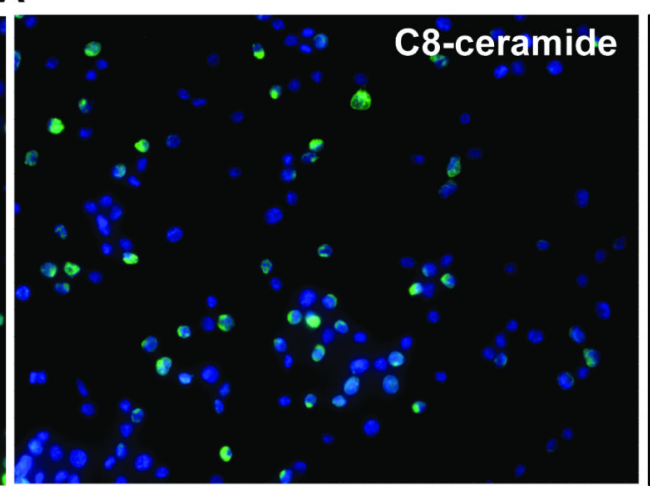

B

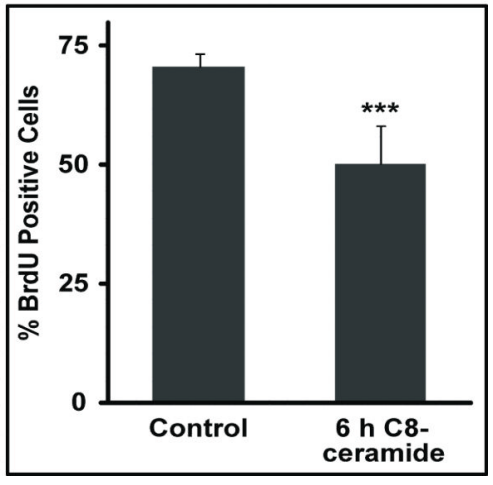

Fig. 7.

Exogenous C8-ceramide inhibited BrdU incorporation in BV-2 cells. (A): Representative images of BrdU uptake in BV-2 controls and cells treated with exogenous C8-ceramide. Cells were plated in 96-well plates and allowed to attach overnight, then treated with $30 \mu \mathrm{M}$ C8-ceramide for $6 \mathrm{~h}$. The media was then replaced with fresh media containing BrdU and cells were incubated for $2 \mathrm{~h}$. Cells were labeled with anti-BrdU antibody followed by DAPI counterstaining, and imaged. Blue: DAPI, green: BrdU. Original magnification 200x. (B): Quantification of BrdU-positive cells as a percentage of total cells. Two sets of images were captured from 4 wells each from controls and C8-ceramide treated. *** $\mathrm{p}<0.001$ compared with controls by unpaired $t$-test. 


\section{Table 1}

DAG levels (nmol/mg protein, 2 fatty acids per DAG; primarily 16:0; 18:0; 18:1; 18:2, 20:4 minor) in BV-2 treated with $100 \mu \mathrm{M}$ D609,

\begin{tabular}{|cccc|}
\hline Control $(\mathbf{n}=5)$ & $\mathbf{2}$ h D609 $(\mathbf{n}=5)$ & $\mathbf{2}$ h D609/2 h $(\mathbf{n}=4)$ & 2h D609/24 h $(\mathbf{n}=4)$ \\
$1.77 \pm 0.17$ & $2.14 \pm 0.08^{*}$ & $2.25 \pm 0.14^{*}$ & $2.18 \pm 0.32^{*}$ \\
\hline
\end{tabular}

( $\mathrm{p}<0.05$ compared to control) 


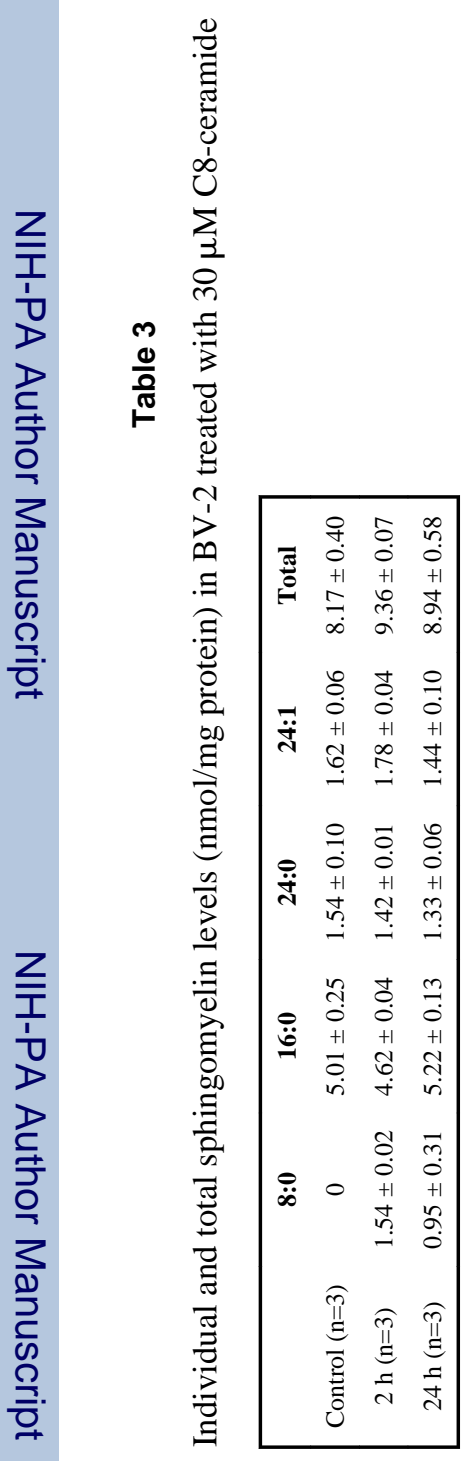

Mol Neurobiol. Author manuscript; available in PMC 2012 June 25. 


\section{Table 4}

C8-ceramide levels $(\mu \mathrm{M})$ in culture media after adding to media at $30 \mu \mathrm{M}$.

\begin{tabular}{|lcccc|}
\hline & $\mathbf{0 ~ h}$ & $\mathbf{2} \mathbf{h}$ & $\mathbf{8 ~ h}$ & $\mathbf{2 4} \mathbf{~ h}$ \\
Media alone $(\mathrm{n}=2)$ & $27.5 \pm 0.17$ & $26.3 \pm 0.01$ & $27.6 \pm 0.16$ & $31.1 \pm 3.5$ \\
Media from BV-2 $(\mathrm{n}=3)$ & - & $16.3 \pm 1.3$ & - & $0.7 \pm 0.3$ \\
\hline
\end{tabular}

